\title{
Lost Boys, Found Church: \\ Dinka refugees and religious change in Sudan's second civil war
}

Sudan's second civil war, which began in 1983 and ended in 2005, transformed society in southern Sudan. A key factor in this transformation was the widespread displacement the war brought about. Some southern Sudanese sought refuge in remote communities within the country or in government-controlled cities such as Juba or Khartoum. But a major stream of displacement was across international borders. By 1987, there were hundreds of thousands of southern Sudanese living in an archipelago of camps in southwestern Ethiopia. When the Ethiopian government was overthrown in 1991, the focus of refugee life shifted to new camps in Kenya, Uganda, and Sudan.

In this, Sudan's civil war was unexceptional. The conflicts that have formed and deformed African societies in recent generations have reliably resulted in both internal and external displacement. During Sudan's first civil war in the 1960s, many southern Sudanese took refuge in Uganda. In the 1970s and early 1980s, the relationship reversed: Ugandans fleeing violence in their own country were living in southern Sudan. By the early 1990s, the relationship reversed yet again as southern Sudanese again sought safety in northern Uganda. The African continent has consistently been among the top producers of refugees in the world, who have been the focus of academic study in a range of disciplines.

The experience of displacement in sub-Saharan Africa has coincided with the rapid growth of Christianity in the region. The future history of the church, it is said, will be written outside its historic heartlands in the Euro-Atlantic world and in no place more fully than in Africa. Yet little work has been done to connect these two trends: on the one hand, displacement, on the other, Christian conversion. ${ }^{\mathrm{i}}$

The refugees of Sudan's second civil war generated an historical record that allows the careful study of the religious life of these displaced communities. Reports from church 
leaders survive in archives in South Sudan. When they are supplemented with fieldwork interviews with former refugees and reports from international nongovernmental organizations, they demonstrate how displacement led to religious change among the refugees, as many left behind existing religious beliefs and turned to Christianity.

In this paper, I focus on the plurality of Sudanese refugees who were Dinka, the largest ethnic group in southern Sudan, and in particular on the large proportion of young male refugees who were apparently unconnected to any family or adult support. Known first as 'unaccompanied minors,' in time this group of approximately 20,000 to 30,000 young people became known as 'The Lost Boys of Sudan.' In the course of more than fifteen years in refugee camps, the focus of their religious practice dramatically shifted. Whereas at the beginning of the war, the majority of these young people adhered to existing Dinka religious beliefs, by the end of the war they had come to understand their religious identity primarily in Christian terms - and had become agents of further religious change. As the course of the war began to shift in the 1990s, some of these young people returned to their homes as Christian evangelists and began to build churches where there had previously been none.

The paper begins by documenting the unstable situation these Dinka young people encountered in refugee camps in Ethiopia to understand how the church was able to emerge as a central social institution. Later, as the refugees were forced to move to new camps in Kenya and Uganda, the paper demonstrates how the comparative stability of these new camps created an environment in which the church could consolidate its growth and begin to build the institutions made necessary by the rapid growth.

Several important implications follow from this study. First, wartime displacement is not a passive activity. Refugee camps are not places of stasis, in which refugees merely bide their time until they can return home. Refugees have agency. Seen in religious terms, wartime was not only a destructive but generative activity for these displaced populations. Second, the 
experience of the displaced young people shows the breadth of resources found in Christianity. Separated from their traditions and culture and living in a harsh new environment, they found in the Christian narrative education, community, and resilience that enabled them to create a new religious identity suited to their new environment. For these young people, the new identity they found in Christianity drove them to accept the truth claims of the new religion.

As the unaccompanied minors became known as 'The Lost Boys of Sudan,' they generated considerable sympathetic media attention. But it is while they were 'lost' that they found - and built — the church.

\section{Ethiopia}

More than fifty years of missionary activity among the Dinka by the Anglican Church Missionary Society and the Catholic Verona Fathers Mission in the early twentieth century produced a weak and fragile church that drew largely from a small educated class and had little purchase in wider Dinka society. When missionaries were expelled in 1964, Dinka religious life was still largely characterised by a set of religious beliefs that centred on animal sacrifice and a high god known as Nhialic, who was accessed through a series of intermediary divinities, collectively glossed as jak. These beliefs grew out of the agropastoralist life of the Dinka, which was centred on cattle husbandry. There was some modest religious change towards Christianity in the 1970s as more Dinka entered into processes of labour migration. Yet by the outbreak of the second war in 1983, most Dinka were not Christian and had little background in education.

The rebel Sudan People's Liberation Army (SPLA) was formed in 1983 and drew much of its senior leadership from Dinka communities. Although it was a Sudanese rebel movement, its headquarters were in southwestern Ethiopia thanks to the support of the 
Dergue regime. ${ }^{\text {iii }}$ In addition to the SPLA, displaced southern Sudanese began arriving in Ethiopia as early as 1983 and finding refuge in camps established by the United Nations. An escalation of violence in 1987 and 1988 led to a sharp increase in the number of refugees. By 1990, it was estimated that there were between 350,000 and 400,000 people in an archipelago of camps at Itang, Dima, and Pinyudu (also spelled Panyido and Fugnido). ${ }^{\text {iv }}$

A notable feature of this population was the large number of young people who lacked adult care-givers. A May 1988 census showed that 45 percent of Pinyudu's population of over 30,000 was male children between the ages of six and fifteen, the vast majority of whom were Dinka. ${ }^{\mathrm{V}}$ Some came from the far western parts of Dinka territory in Bahr el Ghazal along the border with the north but most were from Dinka communities on the east bank of the Nile River. They became known as 'unaccompanied minors' for they had walked without—apparently—adult supervision across southern Sudan to Ethiopia.

Many refugees, but particularly the young people, arrived in very poor health. A group of British Members of Parliament visited the camps in 1988 and found new arrivals 'suffering from disease and malnutrition of a similar severity to that experienced in the 198485 famine [in Ethiopia]. ${ }^{\text {vi }}$ These were the young people who had survived the journey. Studies indicated that as many as one in five of the minors who set out from home died before reaching Ethiopia. ${ }^{\text {vii }}$

War-time migration is a complex phenomenon and it is insufficient simply to draw a causal connection between war and displacement. ${ }^{\text {viii }}$ Some minors later wrote memoirs in which they attributed the displacement to the violence of war and the need for a safe place to seek education. ${ }^{\text {ix }}$ A contemporaneous BBC report quoted a young Dinka man who fled when militias allied with the Khartoum government attacked his home: 'Our houses and villages were set on fire by the government army. We were just looking for survival. No-one encouraged us to come. Either you escape or you die. ${ }^{\mathrm{x}}$ But displacement was also a strategy 
being actively shaped by the SPLA, who recruited young men to their camps in Ethiopia to prepare them for future military service in the training camps it maintained in close proximity to the refugee camps. ${ }^{\mathrm{xi}}$ To the SPLA, the minors became known as jiech amer (Arabic: 'Red Army') and were to be the force that aided them in the war. A human rights NGO concluded that 'the SPLA recruited the boys for both education and military purposes, but attempted to conceal the military purpose. ${ }^{\text {xii }}$ It is claims such as these that make the 'unaccompanied minor' label inappropriate; at least some of the children were accompanied and directed by the SPLA. It also helps explain why this young population was overwhelmingly male: because of Dinka marriage practices, young women were more valuable to families and less valuable to the SPLA as future soldiers.

The military training that many minors received was harsh and difficult and featured extreme physical punishment, starvation, and forced labour. ${ }^{\text {xii }}$ Separated from their families and upbringing, the minors were trained in a way that was designed to destroy any mediating structures of community, loyalty and kinship that would obstruct the recruits' relationship with their military superiors. ${ }^{\text {xiv }}$ The aim was to develop a "nihilistic attitude towards civilians and existing social structures. ${ }^{\mathrm{xv}}$

Nor were the camps administered by the United Nations a safe refuge. Citing security, the SPLA and their allies in the Ethiopian government forbade international workers from staying in Pinyudu, Itang, and other camps overnight. In the camps themselves, the SPLA exercised considerable control over the life of the refugees. The SPLA leadership from time to time convened public gatherings in the refugee camps at which it executed alleged traitors as a demonstration of what would happen if its dictates were not obeyed. The result was an atmosphere that was 'characterised by general fear, apathy, indifference and self-insurance. To stay alive became a cherished idea and this encouraged the culture of silence and insensitivity to all that was happening., ${ }^{\text {xvi }}$ Calling the residents of these camps 'refugees' was 
useful to the SPLA in that it encouraged the international community to respond with aid, which was then redirected towards the training and operational bases the SPLA maintained in safety from the Sudan government. ${ }^{\text {xvii }}$

\section{Young people and the church}

The SPLA was not the only Sudanese organization active in the Ethiopian refugee camps. While most of the young people arriving in Ethiopia were not Christian and had had little exposure to Christianity, a small number were Christian as a result of the modest religious change that had taken place in Dinka communities in the late 1970s and early 1980s. These young Christians became lay evangelists in the refugee camps and began holding informal worship services. One informant recalled how 'They organize[d] rallies in the evening. They [taught] songs. They [taught] the Bible. And most of the people [got] acquainted with [Christianity]. ${ }^{\text {xviii }}$ One of the keys to the success of this evangelism was that it was local. The sheer size of the camps prevented the emergence of a single gathering place for preaching and evangelism. Instead, the lay evangelists began a regular schedule of daily preaching and teaching close to where the young people and others were living.

An important aspect of life in the refugee camps was the strong emphasis on education. All young people, whatever the reason for their arrival in Ethiopia, shared a deep hunger for any form of schooling. The war had laid bare the disadvantage Dinka faced in their relations with the Khartoum government. Education was seen as the way to remedy this deficit. When a United Nations team began assessing education needs in Pinyudu in August 1988, it noted with surprise that refugees had already started their own school system with 15,000 students and no external assistance. ${ }^{\text {xix }}$ The schools were basic and lacked resources. One report described the "crude long structures made of wood and/or mud for the children to sit on. Some do not even have that, and very few have blackboards. ${ }^{\text {xx }}$ No matter the lack of 
resources, the schools became the centre of the minors' life and the place where they concentrated their energy. One refugee recalled the exhortation his teacher gave the class: 'You must do better! You have nothing now, nothing but education. Don't you see this? Our country is in shambles, and the only way we can reclaim it is to learn!... While your older brothers fight this war with guns, when the bullets stop, you will fight the next war with your pens. ${ }^{\text {xxi }}$ By 1988, there were 5500 students in classes in Pinyudu, a small number relative to the total population of the camp, but large in comparison to the lack of educational opportunities in southern Sudan. ${ }^{\text {xii }}$

The emphasis on education coincided with the ongoing evangelical activity. The teachers in the camps were often not trained teachers, but southern Sudanese who had at some point received some measure of education and had been displaced. Both Anglican and Catholic missionaries had relied heavily on schools in their mission activities and the connection between education and Christianity continued after the end of mission period. This close relationship meant that many of these teachers were also Christian. The displacement of the war brought educated, Christian Dinka into contact with non-Christian Dinka in a way that had never before happened. The teachers did not even have to see themselves as Christian evangelists. It was well established that education led to conversion. Unlike the earlier mission period, Dinka youth were now eager for education. Education became 'virtually inseparable' from membership in the church. ${ }^{\text {xiii }}$

It was not only the schools that lacked resources, but the evangelists did as well. In 1989, one visitor reported that there were 'virtually no Bibles...available. ${ }^{\text {xxiv }}$ As a result, music was an important tool for Christian evangelism. Numerous informants remember the importance of songs in their process of conversion. One recalled, 'most of the time, they [evangelists] teach us hymns. But those hymns, when you go home, you wrote them down and sing them again. This is how we start knowing more about God. And that is when I go to 
church and say, 'I want to be baptized." ${ }^{x x v}$ Andrew Mayol Ajak, who became the senior Anglican cleric in Pinyudu in 1988, was explicit about the importance of hymns: 'spiritual songs which quote the Bible cement in what the evangelist says. The sermon happens but then the song makes it stay. ${ }^{\text {xxvi }}$ Hymn composition became a major activity in the refugee camps, and sharing songs became a major activity of the church. A song written in one part of the camp would be memorized or written down, taken to church leaders, and then, if approved, shared with other prayer meetings elsewhere in the camp. The hymns were important not just for their content but also their form. No matter how intensive or extensive the educational efforts, functional illiteracy remained the lot of a majority of Dinka. The skills of learning and transmitting songs, by contrast, had long been at the centre of Dinka culture. In Ethiopia, songs became a primary form of Christian catechesis. Music allowed many Dinka to become Christian regardless of their ability to understand a written text.

Religious change in these refugee camps was aided by the unusual generational patterns of their populations. The religion of the jak was the domain of older men, who guarded their roles as religious and political leaders and sought to prevent religious innovation. But there were fewer older men in the Ethiopian camps; many had either been unable to make the journey or were fighting for the SPLA. In the absence of older men, young boys were unconstrained by religious tradition and unlikely to re-create the rituals and practices of Sudan in Ethiopia. Instead, there was space for religious experimentation. One informant said, 'Spiritual ceremony is part of human life. So if you are separated from the other part, then you consider the alternatives that you can do. And if they see that there is another kind of ceremonial than the one they know, they join. ${ }^{\text {xxvii }}$ The protective function provided by the jak still needed to be filled, even if these divinities were absent in Ethiopia. In a context of war and displacement, Christian conversion was perceived to offer that protection. 
News of the growing interest in Christianity filtered back to Christians in southern Sudan. Church leaders began sending a handful of clergy to the camps. When Anglican priest Andrew Mayol Ajak arrived in Pinyudu in 1988, he found thousands of boys who had been prepared for baptism and were waiting for a priest to administer the rite. On arrival Mayol did 1,601 baptisms in two days. ${ }^{\text {xxviii }}$ By July 1989, a report from the camps identified five ordained Anglican priests (four of whom were Dinka), three ordained Catholic priests (two of whom were Dinka), and several senior commissioned evangelists, both male and female. ${ }^{\text {xix }}$ In total, there were nearly forty lay and ordained church leaders from a variety of denominations and regions in southern Sudan.

No church attendance registers survive from these camps (though they did once exist) but anecdotal reports give an idea of the size of the growing church. A visitor in 1989 found 1500 to 1800 people in church on Sunday. ${ }^{\mathrm{xx}}$ Similarly large services occurred elsewhere as well. In Itang in 1989, over 2000 people were baptized in a single service. ${ }^{\mathrm{xxxi}}$ The following year, Peter Bol Arok, the senior priest in Itang, reported to a visitor that he had done 900 baptisms and that there were 8000 people attending services on Sundays. ${ }^{\text {xxii }}$ In the midst of the hard work of surviving in a poorly-resourced refugee camp, Christian activity came as a welcome break. One informant remembered, 'we went to the church because we didn't have anything. We didn't have our cattle or anything. The only thing that we were looking for was a school. And before we [had] a school, we were just building our houses. So we go to church so that we can go and dance and sing., xxxiii One church leader wrote to a friend, 'Our Lord Jesus is recreating his work in the refugee camps.... there are many big churches in which one can accommodate over three thousand people. ${ }^{\text {xxxiv }}$ At the centre of these churches were the 'unaccompanied' minors who were turning to Christianity in part because of the resources it offered them to survive in their new environment. 
The impact of religious change was seen in the lives of the minors themselves. The church became a focal point of community life. In fact, Christianity became so central that some people began to go just to see what was going on. One informant remembers he first went to a prayer centre meeting because 'I see a lot of people going to church so I would just follow them and see what is going on there.... So I just go there and dance and that's it., ${ }^{\mathrm{xxxv}}$ As time went on, worship services grew in size and frequency, and Christianity became a topic of conversation among refugee minors. More significantly, Christianity helped minors interpret the experience of military training and life in the camps more generally. An informant remembers how 'the community of the church was very important, very, very important. It brings us together. It [was] counseling us. And it provided education. So we were not looking to our pastor as just a pastor but as a father also. ${ }^{\text {xxxvi }}$

The church became an alternate community to the one the SPLA was trying to establish through military conscription. The effects of the church were noticed by the international representatives in the camps. In an extensive report on the minors, the Swedish NGO Rädda Barnen (Save the Children) was surprised to learn that only one percent of minors were classified as 'mentally disturbed' and in need of psychological counseling from its staff. Given the devastation of the war, the organization expected a far higher number. This resilience was attributed, in part, to the way in which 'churches give direction to the otherwise disturbed pattern of life. ${ }^{\text {xxxvii }}$ The circumstances of war and refuge that had brought these minors to these camps made many look at Christianity in a new way. It is unlikely that Christians were a majority in these camps and it is important not to overstate the significance of the church in this period. Nonetheless, the displacement of the civil war, the difficult conditions of the refugee camps, and the need for new resources to assert oneself in a situation of weakness created a set of conditions in which many young people looked at 
Christianity from a new perspective. But the religious change was not permanent and still reversible.

\section{The move to Kenya}

In May 1991, the Dergue was overthrown. The new government rapidly expelled the SPLA and Sudanese refugees from southwestern Ethiopia. In August, the SPLA split along ethnic lines; one branch was commanded by Dinka and another by neighbouring Nuer. In November, Nuer-led force attacked Dinka in and around the community of Bor on the east bank of the Nile River. Thousands were killed and hundreds of thousands more were forced to flee. ${ }^{\text {xxxviii }}$

The events of 1991 had two major impacts on displaced Dinka. First, the refugees in Ethiopia ended up in a new series of camps, both in Sudan and without. Second, these camps were swelled by the addition of hundreds of thousands of newly-displaced Dinka who fled their homes. By 1992, a dominant—indeed, the dominant—feature of Dinka life on the east bank of the Nile was displacement. By the end of that year, seventy percent of the east bank Dinka population had been displaced or killed. ${ }^{\text {xxxix }}$

The church continued to both shape the experience of displacement and be shaped by it. Although Dinka ended up in several camps, this section concentrates on Kakuma Refugee Camp, a camp in northwestern Kenya that opened in June 1992. Kakuma became a central focus for the Dinka church, allowing it to develop institutions that were necessary for it to take deeper root among the Dinka. Kakuma allowed the church to consolidate the growth it had made in the early years of the war and so establish itself as an indigenous institution.

While Kakuma eventually grew and was demographically representative of Dinka society, the first arrivals to Kakuma in June 1992 were those who had fled the Ethiopian camps more than a year earlier. Among the initial 30,000 refugees in Kakuma were many of 
the 'unaccompanied minors' who had been moving among temporary camps in southeastern Sudan for over a year. But they now had a new name. Media reports now began to refer to them as 'The Lost Boys of Sudan,' appealing to the story of Peter Pan and beginning a process of myth-making that would follow some refugees to resettlement in Canada, Australia, and the United States. ${ }^{\mathrm{xl}}$ The church quickly came to take a leading role in organizing new arrivals in Kakuma. It was noticed that among the few items these young people had been able to carry with them from Ethiopia and through a difficult year in Sudan were 'their long wooden crosses and any Bible or hymn book they might possess. ${ }^{\text {xli }}$ It is again important not to overstate the role of the church. But for those who made it to Kakuma, the church was an important social actor in structuring their experience.

Kakuma became a centre of activity for the new Dinka diaspora. Unlike many other new camps for the displaced, it was outside Sudan and so safe from attack. Moreover, the SPLA was a weakened force when Kakuma opened. The loss of its supply lines in Ethiopia and the split in the organization meant its energy was divided and focused elsewhere. The relative weakness of the SPLA meant greater prominence for other institutions among the Dinka. Dinka looking for a social institution they could trust turned to the church.

Yet Kakuma was still insecure. The Nuer-Dinka split in the SPLA did not leave Kakuma unaffected and there was violence between the two groups. Other violence stemmed from Kakuma's location in the territory of the pastoralist Turkana. Some Turkana grew to resent the growing presence of refugees in their midst, not to mention what was perceived to be preferential treatment for the displaced from international organizations. Violence and insecurity was one result. ${ }^{\text {xlii }}$ These challenges were compounded by the difficulty of living in a refugee camp. Refugees were almost completely dependent on aid for survival, even as that aid was reduced for policy and resource reasons. ${ }^{\text {xliii }}$ Many refugees would go several days 
without food, which, in turn, affected their ability to concentrate in school and their susceptibility to disease and illness.

Thus, although Kakuma was more secure than Sudan, life was still fraught. One refugee told interviewers that life in Kakuma 'is like you want to fly, but you have no wings. The days in the camp are horrible. I never dreamt that I would live in such a place. It is hot, dusty, windy. Every day I sit down with my friends in this broken down shelter. We talk, we listen to the radio and in the evening we walk down the street. Every day is the same, but every day is getting worse. ${ }^{\text {xliv }}$ The condition of life was expressed in Christian discourse as well. One hymn composed in Kakuma goes, 'We suffer in the wilderness, we suffer in the forest without homes, enduring thirst and hunger' ${ }^{x l v}$ Even those refugees who were educated and graduated from the schools in Kakuma were stuck in limbo. Kenya made it impossible for them to work legally in the country and there was no possibility of employment in Sudan. Instead, they remained in Kakuma, but with no opportunities for further study or work. ${ }^{\text {xlvi }}$ The particular challenges and obstacles of Kakuma shaped the life of all who lived in it.

\section{The church in Kakuma}

As they arrived in Kakuma, church members began to reconstitute what they had known in Ethiopia. International organizations divided Kakuma into zones, with the Dinka centred in three of these. Each of the three Dinka zones had a lead church where people in the zone gathered for worship on Sunday and other days of the week. In the earliest years, the churches were open-air gathering places that could accommodate thousands. The American priest Marc Nikkel first visited Kakuma in February 1994, twenty months after the camp was established:

On our first Sunday morning, I was sobered to find some six thousand people assembling for the 6:00 a.m.... service in the largest of three open-air churches. These massive forest chapels are set among the thorn trees and spindly, fine-leafed acacias of the region; their meager shade encourages 
worship in the cool of early morning. (I later realized that youth are up as early as 4:30 a.m. laying out handkerchiefs to reserve their places.) The pews are long, smoothed loaves of dried mud, occasionally marked with crosses molded in relief.... on weekdays I sat among three hundred to five hundred 'minors' who gather for prayer at 5:00 a.m. ${ }^{\text {xlvii }}$

As Kakuma grew, more zones were added and the Dinka population spread. As new zones were created, new churches were added as well.

In addition to these central churches, there were smaller gatherings that met more frequently. These groups met for Bible study, prayer, and, crucially, singing. They were known in Dinka as luang de guer or 'evening gathering places,' an indication of when they were used. It is was here that the actual work of conversion and catechesis happened. Again, songs were a primary form of catechesis. In the gathering places hymns were written, collected, shared, learned, and preserved. One informant who was involved in this work recalled: 'We don't have paper in our hands, just memorize them in your mind. So when you come back next time and we start singing again and again and over and over, then that's where we learn all the hymns. ${ }^{\text {xlviii }}$

Christians displaced from the east bank of the Nile joined those from Ethiopia and elsewhere to make the church a larger institution than it had ever been in Ethiopia. This growth was evident in its sacramental ministry. In 1993, Anglican Bishop Nathaniel Garang Anyieth confirmed more than 10,000 people over three days, many of whom were people who had been baptized in Ethiopian camps. ${ }^{\text {xlix }}$ Confirmation was seen, inter alia, as a mature affirmation of faith, distinct from baptism. The events of 1991 had made a return home seem less likely than it had been in Ethiopia. Greater Christian commitment was one result.

The growth of the church was also due to a continued emphasis on education. The 1991 events had again offered proof of the Dinka's need for new resources to assert themselves in the world. Education, more than anything else, was that resource. The skills that had once led to success for Dinka men in cattle camps were no longer sufficient, particularly now that it was clear that a return to those camps was no longer imminent. 
Education had been important in Ethiopia but several factors in Kakuma intensified interest in it. Because refugees were not able to keep cattle, it was not possible for these young men, some of whom were now reaching marriageable age, to pay a bride price and find status through marriage and family. ${ }^{1}$ Without families to rely on, many young men adopted as their slogan, 'Education is your mother and your father." li In a context of familial breakdown, education was seen as the sole means to improve one's condition. Researchers who interviewed refugees in Kakuma reported their overwhelming desire for education. lii $^{-}$

But the desire for education was not matched by its provision. Kakuma had a basic primary school system that could accommodate demand, but for many years only had a single secondary school. In 1995, for instance, there were three thousand students finishing primary school but only two hundred spaces in the secondary school. liii The mismatch between the overwhelming desire for education and its lack of provision intensified a dynamic that had been present in Dinka religious history in which an increased desire for education led to an increased commitment to the church. If students could not attend a secondary school—and many who wanted to could not - they could at least join the church, become part of hymnwriting and hymn-recording, and learn to read the Bible. The church became a near-substitute for the school. Christianity became a way for young people to get ahead in life.

The church began to create institutions to accommodate the growth. Jo Wo Liech (JWL) was the primary church affinity group for young men. ${ }^{\text {liv }}$ Its name is a Dinka phrase that means 'turn back on us.' The name comes from an idea deeply rooted in Dinka Christian beliefs that God was abandoning the Dinka because they had worshipped the jak. Now that Dinka were turning to Christianity, God was beseeched to turn back and remember the Dinka. The comparative stability of Kakuma allowed JWL to grow rapidly. Members of JWL were young, unmarried men in their late teens and early twenties, an age range that included the bulk of the young people who had left home as children and 
come to maturity in refugee camps. They were divided into four loose sub-groups: aluong, whose members were responsible for collecting and documenting songs that were being composed; agayth, which was responsible for Dinka language learning and literacy education; luangic, which translated and taught the Bible; and lek, whose members were responsible for evangelism. There was overlap between the sub-groups, but the division shows the priorities of the church. The leaders of the evening gathering places, for instance, were members of lek, and its members rotated in leadership of the services. As time passed, JWL took on responsibility for producing new resources for the church. Agayth produced at least one Dinka-language primer, Lokku Tueng ne Thoungjieng ('Let us go ahead with the Dinka language'), which was published in 1997. Members of aluong took a leading role in creating a new Dinka hymnal, which was also published in 1997 and included much of the new material that had been composed during the war.

In addition to the practical impact on the development of the church, JWL was important for the belonging and sense of membership that it gave its members. For many young people who were separated from their families, membership in the church as mediated through JWL gave an important sense of community they were lacking elsewhere. One favourite Bible verse of many JWL members was Psalm 27:10: 'If my father and mother forsake me, the Lord will take me up'. Many JWL members frequently rendered this verse without the conditional as 'Your mother and father have deserted you but God will never desert you. ${ }^{\text {lv }}$ Membership in JWL came to be highly desired and people could only belong if they were members of the church in good standing. As a result, church membership and attendance was encouraged, not just in verbal exhortation and evangelism, but in the developing system of social rewards that was being created in Kakuma.

The growth of the church was seen in expanding zonal churches, affinity groups, and a new Christian publications. The impact of this growth was seen in the lives of the displaced 
young people, an impact that was widely noted by those who interacted with them. Kakuma attracted a variety of aid workers with extensive international experience. A consistent theme of their reports is that the refugees they encountered in Kakuma were in better psycho-social state than their past experience would lead one to believe. Julianne Duncan, who worked for an American Catholic organization interviewing minors prior to their resettlement abroad, recalled that based on her prior experience in refugee camps, 'If children have been brutalized and treated badly, they themselves will have psychic wounds that can't be healed. This will come out in anti-social behaviour, psychotic behaviour. That's a kind of truism.' Among the people she worked with in Kakuma, however, 'I didn't really see that. I attribute this to the very kindly cadre of caretakers who were guiding them through Christianity., lvi Later, when Duncan worked with these same refugees after they had been resettled in the United States, she concluded that 'the population had considerable strength and resiliency. The major protective factors were belief in God, desire for and success in education, [and a] desire to be helpful to society in the future. ${ }^{\text {,vii }}$ Although these refugees did exhibit signs of mental health distress, it was less than experience would lead one to believe and it was being coped with in a largely successful manner. ${ }^{\text {lviii }}$ She roots this behaviour in their Christian commitment. Non-religious observers noted these trends as well. United Nations staff found the minors - to their surprise - to be 'cheerful, patient, cooperative, sensitive and...courageous., lix

Young people in Kakuma found in Christian narratives resources that allowed them to hope for the future. The Christian narrative gave refugees a sense of status that living in a refugee camp could take away. One resident of Kakuma said that refugees 'have the feeling that God is supporting us.... It is also God who will take care of us in our future because we call his name. ${ }^{\text {lx }}$ The Christian faith became a coping mechanism for people who were losing hope. As one said, 'Our religion is strengthening us, otherwise I would have mentally broken 
down. God knows what he is doing. We leaving everything in his hands. He is the only one who knows the cause of everything., ${ }^{\text {lxi }}$ For those who had experienced combat and the brutalizing impact of SPLA training, Christianity gave converts a new moral universe that allowed them to question their past behaviour. ${ }^{\text {1xii }}$ In general, Christian beliefs and practices made Lost Boys more hopeful about the future. ${ }^{\text {lxiii }}$ Yet the impact of Christian conversion should not be overstated. The church was not a panacea for the problems many young refugees faced. 'Lost Boys' may have been more resilient than other refugee populations but many suffered psycho-social distress. The church in Kakuma waxed and waned at various points. Still, of those who wound up in Kakuma, the church became an institution of central importance, one which many young refugees turned to at a time of need.

Kakuma intensified and deepened the trends that were apparent in Ethiopia. The changed circumstances of the war made many of them look at Christianity in a new way. It gave them new resources (or the hope of new resources) not only in education but also in a system of social rewards and a way to interpret their experience of the war. The result was a shift in religious identity. Dinka young men were now more likely—overwhelmingly so, in fact - to identify as Christian, even if that faith played a varying role in their life and as a tool to cope with the challenges of displacement. The widely apparent impact of Christian conversion became noted with some irony. The SPLA's intention of creating an army of youth who could fight the war - the jiech amer- had been subverted by the refugees themselves. Rather than creating a military army, the children who had left home in the 1980s were now a Christian army-a church. .xiv $^{\text {- }}$

\section{Returning home}

In the late 1990 s and early 2000 s, a small minority of unaccompanied minors were resettled in the United States, Canada, Australia, and elsewhere, where their story became 
widely known as a result of intense media coverage and the ability of many 'Lost Boys' to tell their story in a compelling fashion. But most remained in east Africa. Even before the end of the war came into view in the early 2000s, some continued to move. This had implications for the spread of Christianity, which are seen most clearly in the growth of Dinka Anglicanism.

The territory around Aweil and Wau in the westernmost regions of Dinka territory had been in the region the colonial government allocated to Catholic missionaries. There was an expectation that if Dinka from these areas were Christian, they were Catholic. In the early 1990s, anthropological fieldwork concluded that about fifteen percent of western Dinka were Christian. ${ }^{\mathrm{lxv}}$ A minority of the young refugees in Ethiopia were from this area, however, and some were baptized as Anglicans. When the refugees were expelled from Ethiopia in 1991, not all of them ended up in Kakuma or another displaced camp. In the confusion of war, going home was for some people an option that seemed to provide the most safety. For instance, one young baptized Anglican refugee, Santino Bol, had an uncle who was a commander in the SPLA and based in their home region around Aweil. The Sudan Armed Forces controlled a handful of towns like Aweil and Wau, but the vast rural areas were largely under the control of the SPLA. Bol found he could live in relative safety under his protection. ${ }^{\text {xvi }}$ The initial Anglican presence in Aweil came simply from the ongoing displacement of the war.

But there was also a deliberate Anglican missionary effort. Wilson Garang, who had been in the Ethiopian camps, was ordained by Anglican Bishop Nathaniel Garang in 1992 in a refugee camp on the Sudan-Uganda border. Nathaniel Garang sent Wilson Garang to his home region near Aweil as an evangelist. Wilson Garang relied on people like Santino Bol and others who had had some Christian knowledge from their time in Ethiopia to act as evangelists in the area around Aweil, where they could work with relative freedom among the 
Dinka. Between 1993 and 1994, Wilson Garang claimed to have baptized 5000 people. $^{\text {1xvii }}$ Even allowing for the exaggeration of self-reporting, it still represents a significant accomplishment in a region in which there had previously been no Anglicans. As was the case elsewhere in southern Sudan, many of these early converts were women. In parallel with the growth of Dinka Christianity in refugee camps, the church had been growing in SPLAcontrolled areas in southern Sudan, with women at the forefront of this change. Detailed examination of the gendered implications of religious change is beyond the scope of this paper.

The key figures in the growth of the church around Aweil were those who had left their homes in the turmoil and disruption of the early years of the war. They returned as Christians, which they had not been when they left. They received support from Nathaniel Garang, who was officially appointed the caretaker bishop in 1996 as the region had no resident Anglican bishop. In this role, Bishop Garang visited in April 1998 and conducted the first Anglican ordinations in the Aweil area. Many others were consecrated as lay readers or commissioned evangelists. Of the twenty-one men ordained then, eleven had spent time in Ethiopia and/or Kakuma and saw themselves as members of the Jo Wo Liech. ${ }^{\text {lxviii }}$

Even as the church took root in Aweil, it maintained its links with the larger Dinka diaspora through continued movement. For instance, Stephen Mou was a young Christian who had been in Ethiopia and Kakuma. In 1997, he returned his home in the Aweil area, bringing with him knowledge of the nascent Dinka hymnal. He was assigned to teach pastors and evangelists the hymns that were motivating church members in Kakuma and elsewhere. In this way, knowledge in one part of the church spread to another, furthering the growth of the Christian movement.

The growth of Anglicanism is demonstrated by the ire it raised among the Catholic church. In this region, there was a network of Catholic parishes concentrated in towns. 
Outlying stations were served on a sporadic basis by 'pastoral safaris' in which a priest visited two or three times a year to offer a limited sacramental ministry. ${ }^{\text {lxix }}$ This contrasted sharply with the Anglican approach. The young Anglican evangelists were largely unable to access the towns, but the internal displacement caused by the civil war meant that the Dinka they sought to convert were in the rural areas. Moreover, differing approaches to ordination meant that there were few Dinka Catholic clergy. Indeed, most of the priests in the Catholic Diocese of Rumbek in which this region fell were from abroad. Within a few years, however, there were seven Anglican clergy in the region, all of whom were native to the region and stationed there, compared to five Catholic Sudanese clergy, not all of whom were native Dinka speakers and only three of whom were actually stationed in southern Sudan. ${ }^{\mathrm{kx}}$ During the colonial period, there had been far more Catholic than Anglican missionaries in southern Sudan. The balance was now reversed: there were more Anglican lay evangelists and clergy in the region than there were Catholic and they were positioned in the parts of the region where most Dinka were actually living.

The report of the Catholic diocese's annual assembly in February 1999 records that 'there have [sic.] been infiltration of foreign protestant brothers and sisters, who through giftgiving try to obtain apostasy of young and old from the catholic faith to some protestant denomination.' The report concludes that it is necessary to ask 'for the intervention of the civil authorities to dispel this christian or non-christian intrusions and respect the traditional religious affiliation of the people. 'lxxi In this case, 'traditional religious affiliation' referred to the historic spheres established during the colonial period. In a further reversal of that period, it was now the Catholics who thought the Anglicans were infringing on their territory.

The limitations of space prevents a fuller examination of the growth of Anglicanism in northwestern Bahr el-Ghazal. In particular, the role of the SPLA in facilitating the travel and protection of these evangelists needs further study, as well as the relatively weak role of 
education in Christian conversion, in contrast to experience elsewhere. Further work as to how returning refugees integrated into church structures in Anglican areas that had grown in their absence is also necessary. But the larger point is the impact of the continued movement of Dinka young people on the growth of the Anglican church in southern Sudan. Migrants who had moved first to Ethiopia and Kenya returned home as Christian evangelists and planted the seeds of a new church.

\section{Conclusion}

In an influential article, the Africanist anthropologist Robin Horton argued that the key to understanding religious change in Africa was the 'shattered microcosm.' As social and economic change transformed African societies from local and small scale to primarily urban and cosmopolitan, he argued that religious change would naturally follow. ${ }^{\text {xxii }}$ There has been extensive debate around Horton's thesis, virtually all of which draws on case studies from the colonial period. Yet international displacement to refugee camps is an example of a shattered microcosm. The displaced young people were brought into contact with a world of formal education, international organizations, rebel movements, and, in time, refugee resettlement. For young Dinka refugees, this movement generated a need for a new religious identity, which many found in Christianity. In the education offered by Christianity and the promise it held for future assertiveness, many young Dinka men found a religious identity and community which helped them navigate and make sense of the war that was taking place around them. They were freer to adopt this new religious identity because the displacement of the war had removed obstacles to conversion that had previously been presented by older men and other authority figures in society.

Refugees are frequently depicted as passive, immobile recipients of aid who bide their time through the good graces of others until they can return home. ${ }^{\text {lxiii }}$ The trajectory of the 
unaccompanied minors challenges this view. The Dinka who left their homes in the 1980s, first for Ethiopia and then for Kenya and elsewhere, sought Christian conversion and used that conversion as a motive force towards education and evangelism. The refugee camps of Pinyudu, Itang, Kakuma and elsewhere were not places where they simply went to wait. They were, instead, staging grounds for further church growth and development. In Christianity, refugees found mutual aid, education, community, and a set of beliefs to interpret the situation in which they found themselves.

In one sense, this study of religious change is unexceptional in the study of African Christianity. The role of education, the appeal of Christianity to young people, and the connection between migration and change have been highlighted in other studies. What this paper has shown is the way in which these processes of conversion were set in motion by a uniquely post-colonial event, namely an African civil war. The social life of refugees needs to be more closely studied and seen as dynamic as any other social life regardless of location. If the future history of the church is a non-western history, it must include a sustained focus on displacement. 
${ }^{\text {i }}$ Two articles that do are Elżbieta M. Gożdziak and Dianna J. Shandy, 'Editorial introduction: Religion and spirituality in forced migration,' Journal of Refugee Studies (hereinafter $J R S$ ) 15.2 (2002): 129-135 and K.B. Wilson, 'Refugees \& returnees as social agents: The case of the Jehovah's Witnesses from Milange,' When Refugees Go Home: African Experiences, eds. Tim Allen and Hubert Morsink (Trenton, NJ, 1994), 237-250. ${ }^{i i}$ Godfrey Lienhardt, Divinity and experience: The religion of the dinka (Oxford, 1961). iii Douglas H. Johnson and Gerard Prunier, 'The foundation and expansion of the Sudan People's Liberation Army,' in Civil War in the Sudan, eds. M.W. Daly and Ahmad Alawad Sikainga (London, 1993): 117-141.

iv Sharon E. Hutchinson, Nuer dilemmas: Coping with money, war, and the state (London, 1996), 6.

${ }^{\mathrm{v}}$ United Nations High Commission on Refugees Technical Support Service (UNHCR TSS), 'Ethiopia: Unaccompanied children in Fugnido: A preliminary study, 30 May-28 June 1988,' TSS Mission Report 29/88, 1 (Archive of UNHCR, hereinafter UNHCRA).

${ }^{\text {vi }}$ House of Commons Foreign Affairs Committee, 'Famine in the horn of Africa,' 12 May 1988, Session 1987-88, HC 297, xxvii.

vii Sheila Rule, 'Refugees from Sudan strain Ethiopia camps,' New York Times, 1 May 1988. viii Stephen C. Lubkemann, Culture in chaos: An anthropology of the social condition in war (London, 2008), 15-21.

${ }^{\text {ix }}$ See, for instance, Abraham Nhial and DiAnn Mills, Lost Boy no more: A true story of survival and salvation (Nashville, TN, 2004) or John Bul Dau with Michael S. Sweeney, God grew tired of us: A aemoir (Washington, D.C., 2007).

${ }^{\mathrm{x}}$ Mike Wooldridge, 'Why they fled,' in War wounds: Development costs of conflict in southern Sudan, eds. Nigel Twose and Benjamin Pogrund (London, 1988), 142. 
${ }^{x i}$ Carol Berger, 'Southern Sudan's Red Army: The role of social process and routinised violence in the deployment of underaged soldiers,' (D.Phil. dissertation, Oxford, 2010). xii Human Rights Watch, Civilian devastation, 205.

xiii Berger, 'Southern Sudan's Red Army,' 110-111.

${ }^{\text {xiv }}$ Sharon E. Hutchinson, 'A curse from God? Religious and political dimensions of the post1991 rise of ethnic violence in South Sudan,' The Journal of Modern African Studies 39.2 (2001), 315 .

${ }^{\mathrm{xv}}$ Rolanda Oostland and Ronald Berkvens, Sudanese life stories: Voices from Kakuma Refugee Camp (London, 1998), 34; Nyaba, Politics of liberation in South Sudan, 55; African Rights, Food and power in Sudan: A critique of humanitarianism (London, 1997), 82. ${ }^{x v i}$ Nyaba, Politics of liberation in South Sudan, 67. xvii African Rights, Food and power in Sudan, 73. xviii Author interview, Daniel Kon Malwal, Bor, South Sudan, 5 April 2013.

${ }^{\text {xix }}$ UNHCR TSS, 'Ethiopia: Assessment of the psycho-social needs of children in the Fugnido camp, 8-22 August 1988,' TSS Mission Report 39/88, 3 (UNHCRA).

${ }^{\mathrm{xx}}$ UNHCR TSS, 'Ethiopia: Unaccompanied children in Fugnido,' 4. ${ }^{x x i}$ Eggers, What is the what, 297.

xxii Rädda Barnen, 'The unaccompanied minors of southern Sudan,' 34 (Archive of the New Sudan Council of Churches, Juba, South Sudan; hereinafter NSCCA); African Rights, Food and power in Sudan, 80. The archive of the NSCC in Juba is in poor condition and lacks organization or a catalogue making specific citation difficult. The author retains a photographic record of every document from the archive cited in this paper.

xxii African Rights, Food and power in Sudan, 80.

xxiv John Boyer, 'Assistance to Sudanese refugees in south west Ethiopia,' November 1989, 8 (NSCCA). 
${ }^{\mathrm{xxv}}$ Author interview, Gabriel Chol Kuany, Phoenix, Arizona, 26 June 2012.

${ }^{x x v i}$ Author interview, Andrew Mayol Ajak, Juba, South Sudan, 4 April 2013.

${ }^{\text {xxvii }}$ Author interview, Daniel Kon Mawal.

xxviii Author interview, Andrew Mayol Ajak.

${ }^{\text {xxix }}$ Open letter from Christians in the refugee camps, 9 July 1989 (NSCCA).

${ }^{\mathrm{xxx}}$ John Boyer, 'Assistance to Sudanese refugees in south west Ethiopia,' 7.

${ }^{x x x i}$ Marc Nikkel, Dinka Christianity: The origins and development of Christianity among the

Dinka of Sudan with special reference to the songs of Dinka Christians (Nairobi, 2001), 239.

${ }^{x x x i i}$ Timothy Biles, Windows on the Sudan: A story of pain and pride, 3rd ed. (Dorset, 1994

[1991]), 80.

xxxiii Author interview, Mark Deng Bul, Phoenix, Arizona, 21 July 2012.

${ }^{\text {xxxiv }}$ Abraham Mayom, letter to Marc Nikkel, 13 June 1989 (NSCCA).

${ }^{\text {xxxv }}$ Author interview, Gabriel Chol Kuany.

${ }^{x x x v i}$ Author interview, Abraham Yel Nhial, Aweil, South Sudan, 19 July 2011.

${ }^{\text {xxxvii }}$ Rädda Barnen, 'The unaccompanied minors of southern Sudan,' 8, 45.

xxxviii As with many aspects of Sudan's civil war, exact numbers are impossible to determine.

Tvedt estimates that 5000 were killed. Tvedt, et al., An annotated bibliography on the southern Sudan 1850-2000 (Bergen, 2000), 901.

${ }^{\text {xxxix }}$ Sharon Hutchinson, 'Spiritual fragments of an unfinished war,' in Religion and African Civil Wars, ed. Niels Kastfelt (London, 2005), 37.

${ }^{\mathrm{xl}}$ Mark Bixler, The Lost Boys of Sudan: An American story of the refugee experience (London, 2005).

xli Andrew C. Wheeler, 'Finding meaning amid the chaos: Narratives of significance in the Sudanese church,' in Religion and African Civil Wars, ed. Niels Kastfelt (London, 2005), 60. 
${ }^{x l i i}$ M. Jan Holton, Building the resilient community: Lessons from the Lost Boys of Sudan (Eugene, OR, 2011), 77; Linda Bartolomei, Eileen Pittaway, and Emma Elizabeth Pittaway, 'Who am I? Identity and citizenship in Kakuma refugee camp in northern Kenya,' Development 46 (September 2003): 88.

xliii Guglielmo Verdirame, 'Human rights and refugees: The case of Kenya,' JRS 12. 1 (1999): 62 ${ }^{x l i v}$ Quoted in Oostland and Berkvens, Sudanese life stories, 60.

${ }^{x l v}$ Quoted in Marc Nikkel, 'Songs of hope and lamentation from Sudan’s ‘Unaccompanied Minors,' Sewanee Theological Review 40:4 (1997): 490.

${ }^{x l v i}$ Oostland and Berkvens, Sudanese life stories, 66.

${ }^{\text {xlvii }}$ Marc Nikkel, letter to supporters, 15 April 1994, in Why haven't you left? Letters from the Sudan, ed. Grant LeMarquand (New York, 2006), 108.

xlviii Author interview, Gabriel Chol Kuany.

${ }^{\text {xlix }}$ This number is unverifiable but that such a service took place is widely attested by a variety of sources. See, for instance, Hugh McCullum, 'Ministering during war,' One World (June 1995): 14 (NSCCA); Nikkel, 'Songs of hope and lamentation,' 490.

${ }^{1}$ Sabine Knoedlstorfer, 'Kakuma Refugee Camp: A report,' (Berlin: March 1999), 27 (NSCCA).

${ }^{\text {li } M a r t i n ~ M a s u m b u k o ~ M u h i n d i ~ a n d ~ K i g a n z i ~ N y a k a t o, ~ ' I n t e g r a t i o n ~ o f ~ t h e ~ S u d a n e s e ~ ' L o s t ~}$ Boys' in Boston, Massachusetts USA, 2002,' 7.

lii Johannes Zutt, Les Enfants de la Guerre: Seuls dans la vie au sud du Soudan (New York, 1994), 30.

liii Marc Nikkel, letter to supporters, 10 October 1995, in Why haven 't you left? 137.

liv The history of Jo Wo Liech in the following paragraphs is rooted in interviews with its members. 
${ }^{\text {lv }}$ Marc Nikkel public talk, Rochester, New York, USA, 25 April 1997. Video recording privately held by Nancy Frank.

${ }^{\text {lvi }}$ Author interview, Julianne Duncan, 12 January 2013, telephonically.

lvii Julianne Duncan, 'Sudanese 'Lost Boys' in the United States: Adjustment after six months,' United States Catholic Conference, 30 May 2001, 2

lviii On this question, see also the work of Jan Holton, who has made an extensive study of the question of resilience among 'Lost Boys': Holton, Building the resilient community, 110.

${ }^{\text {lix }}$ UNHCR Programme and Technical Support Section, 'Kenya: Registration and needs assessment of southern Sudanese minors, 15 July-3 September 1992,' PTSS Mission Report 92/32, vii (UNHCRA).

${ }^{1 x}$ E. Linnemeyer, 'The religious experience of Sudanese refugees: Kakuma refugee camp, October/November 1996,' paper presented at 'Sudan Church Study Seminar,' Feb. 1997, Limuru Kenya, 19 (NSCCA).

${ }^{1 x i}$ Quoted in Oostland and Berkvens, Sudanese life stories, 57.

${ }^{1 x i i}$ Hutchinson, 'Spiritual fragments of an unfinished war,' 37.

1xiii Elijah M. Brown, 'The road to peace: The role of the southern Sudanese church in communal stabilisation and national resolution,' (Ph.D. dissertation, University of Edinburgh, 2008), 44 .

lxiv Wheeler, 'Finding meaning amid the chaos,' 60.

${ }^{1 x v}$ Jok Madut Jok, Militarization, gender and reproductive health in South Sudan (Lampeter, UK, 1998), 112.

${ }^{1 x v i}$ Author interview, Santino Bol, Nakuru, Kenya, 26 September 2013.

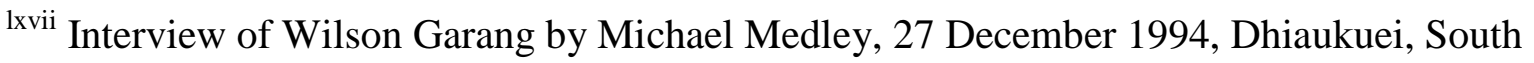
Sudan (transcript held privately by Michael Medley).

${ }^{\text {1xviii }}$ Marc Nikkel, letter to supporters, 31 May 1998, in Why haven't you left? 168-169. 
${ }^{1 x i x}$ The Diocese of Rumbek at a glance, 1998, 5 (NSCCA).

${ }^{1 x x}$ The statistics for the Anglican clergy are taken from letter of Wilson Garang Chan to Daniel Zindo, 30 Sept. 1996, now in the personal papers of Nathaniel Garang Anyieth. The statistics for the Catholic clergy are taken from 'List of diocese of Rumbek church personnel in South Sudan and Kenya, 24 Sept. 1999’ (NSCCA).

${ }^{\text {lxxi }}$ Diocese of Rumbek, 'Annual assembly report, Nairobi, February 1-6, 1999,' 5 (NSCCA). 1xxii Robin Horton, “African conversion,” Africa 41. 2 (1971): 85-108.

lxxiii Roger Zetter, 'Labelling refugees: Forming and transforming a bureaucratic identity,' JRS 4.1 (1991). 